International Journal of Trend in Scientific Research and Development (IJTSRD)

Volume: 3 | Issue: 2 | Jan-Feb 2019 Available Online: www.ijtsrd.com e-ISSN: 2456 - 6470

\title{
Social Media Marketing and Small Business
}

\author{
Ramandeep Kaur \\ Assistant Professor, Department of Business Management, \\ Gujranwala Guru Nanak Institute of Management \& Technology, Ludhiana, Punjab, India
}

\begin{abstract}
Today, we are in 21st century and people do not find time to come \& interact with each other. Social media helps in connecting themselves with social networking sites through which now people can stay far and yet remain connected. Social media also create a platform to post comment on any event which needs to be publicized and also can be utilized as a promotional technique. These days' Social media applications have become most efficient and effective tool for small business entrepreneurs because of cost effectiveness and almost all small businesses are using social media to advertise and market their products and services. They make fan pages for the followers and they welcome the suggestions and opinions which help in improving their business. The objective of this research paper is to find out the strategies which can be used by small business entrepreneurs and its impact on building their community strong enough to make marketing effective \& initiative buying.
\end{abstract}

Keywords: Social Media, blogs, small business, entrepreneurs

\section{INTRODUCTION}

Social media marketing refers to the process of increasing popularity of product and services through social media sites. Social media marketing actually focus on efforts to create content that attracts attention of the customers and share the information on social media networks. A product message spreads from customer o customer appears to come from a trusted source, as opposed to the brand or company itself. Social media has become a platform that is easily accessible to anyone with internet access. Increased communication for organizations fosters brand awareness and offer improved customer service. Additionally, social media serves as a relatively inexpensive platform for organizations to implement marketing strategies.

Social networking websites allow individuals to interact with one another and build relationships. When companies join those sites, people can interact with the product or services or company. That interaction feels personal to users because of their previous experiences with social networking site interactions. Social media in business allows anyone and everyone to express and share an opinion or idea somewhere along the business's path to market. Each participating customer becomes part of the marketing department, as other customers read their comments or reviews. Social networking sites like Twitter, Facebook, Google Plus, YouTube, Pinterest and blogs allow individual followers to "retweet" or "repost" comments made on the product being promoted. By posting the message, all of the users connections are able to see the message, therefore reaching more people. On social networking sites the information about the product is being put out there and when it get repeated, more traffic is brought to the product and company. Through social networking sites, products/companies can have conversations and interactions with individual followers. This personal interaction can bring a feeling of loyalty into followers and potential customers. Also, by choosing whom to follow on these sites, products can reach a very narrow target audience. Cell phone usage has also become a benefit for social media marketing. Today, many cell phones have social networking capabilities in real-time. This constant connection to social networking sites means products and companies can constantly remind and update customers about their capabilities, uses, importance, new offers, products etc. Now many companies are putting QR codes along with products to access the company's website or online services with their smart-phones. With the passage of time, no doubt that technology is becoming faster and faster as well as making lives of individuals easier, on the other hand the businessmen are taking advantage of this facility to bring new ideas.

\section{Literature review:}

Since the inception of Social networks in 1997, with the launching features of blogging and posting through web 2.0 named as six degress. com. The basic purpose of this site was to facilitate people in terms of social connectivity LinkedIn, My Space as well as advance mode of face book and other software's like Orkut, Google talk, Skype, Hangout and whatup etc. Cheung and Lee stated that, "the decision to use online social networking technologies represents a social phenomenon that largely depends on the interactions" and concludes observing that "the driving forces behind online social networks are connections and community, and the usage is largely depended on subjective norm and social identity". Mangold and Faulds defined that "Social media is a hybrid element of promotion mix because in traditional sense it enables companies to talk their customers while in a non-traditional sense it enables customers to talk directly to one another. The key factor behind the performance of Management is based as team work, while the progress of employee's depending upon leadership of the management. However, the term management is not only consisting on firm level but also for Institutions, Economy and State levels respectively Shahzad and Rehman. With the help of social media people enjoying their lives smoothly and remain connect with their love-ones, as well as it provides salient pieces of information for different purposes, social media can be named as consumer generated media, new media and citizen media. 


\section{Social Media and Small Business}

All most all business takes into consideration of usage of social media in order to market / branding some product. Small businesses use social media application as a marketing tool for the branding and marketing of their products. Based on survey it was found that application of social media by businesses is inclined more towards branding, communication to the customer and building strong customer relation. The strategies of small business are to adopt micro blogging to make direct connect with individual who has some interest in their business or product. Social media helps small business entrepreneurs to build their small community over that media for smooth interaction with their customers. There is a new trend of using facebook by small business users due to cost as well time saving in order to promote their products. A study suggests that by using social media, entrepreneurs could connect to their customers even more effectively than by tradition marketing.

Now days, small businesses use various applications in social media to enhance their business growth as well as for publicity. As, large number of same field business join their pages that's why they earn more and share knowledge with each other which results in expansion of their businesses. Small business use social media more because it is all about socializing and sharing opinions. These opinions can be expressed as written entries in the form of blog posts or comments, video presentations on social media sites. The openness of these opinions is one of the main changes social media introduced to the relationship between business and customers. It builds a relationship of trust in business and customer.

Entrepreneurs use social media as a marketing tool because through this tool they can build quickly a network of supporters which is vital for business growth. Because these supporters keep bring customers for small business entrepreneurs by referring it to others. Social media helps to create a long term relationship between businesses and customers. But there is some issues relating to social media is that implementation of social media technologies are so dynamic and there has not been a clear guideline for businesses as to how to utilize them. Mostly business use their own experimental approach to achieve a better result and this has somehow made the task more challenging. Second is implementing Social Media is the task of setting a clear objective and large number of businesses join the social media every year but those who maintain their online presence effectively are relatively low, this is because many of those businesses launch the social media campaign without clear strategic goal. Probably every business want to experiment the technology because they are attracted by the low cost of entry and can experiment if their business can benefit from social media marketing or not. To overcome these problems entrepreneurs should set objectives in social media marketing process. In order to measure effectiveness of social media marketing, a specific objective should be set. Any marketing campaign without an objective cannot be measured and evaluated and unless we are able to measure the performance it can be considered a waste of an effort. Following are various strategies for using social media marketing process by small business entrepreneurs.

\section{Using More of Videos:}

Consumers in digital world using the web to look for product pictures and videos as they want more information regarding the product. Now days it is easy for companies to publish pictures and videos of products. In addition to this business can also post the videos highlighting the company's work culture. This not only helps to convince others to work with you but also to buy from you. Videos are useful for showing step by step directions that can have a greater impact than even the most well written material. Videos are highly recommended because businesses don't have to invest huge sums of money to create good videos. Relatively cheap Flip camcorder, which takes great videos and is easy for even a non-technical marketer to use. Multimedia can break down the faceless business-to-consumer sales flow and make your company appear friendlier. Use videos and images to show that your business is fun, you care about your employees, and most importantly, that you care about your customers.

\section{Integrate Offline and Online Advertising:}

Many small businesses do some sort of offline advertising including TV, magazines, parties, contests, seminars, workshops, and more. If you are hosting an offline event, bring it online by announcing and promoting it by email and social media. If any of your customers share their positive experience, ask them to write an online review. If you have a particularly memorable and positive experience with a customer, share it on your blog or newsletter. Integrating online and offline advertising help to build your community strong. Introducing potential consumers to your social profiles means they may join your community now and buy later.

\section{Message adaptation:}

As businesses start to become more advanced with the use of social media. Though social media is free, delivering same message over multiple times is not acceptable and might be considered as spam. Entrepreneurs need to understand that each site is different and then customizing messages to ensures they do well on each respective site. Not only does customizing messages across sites help the message spread but it keeps users from receiving multiple identical communications. Be sure to maximize your potential by sending a user that follows the business on Twitter and Facebook different messages, instead of the same.

\section{Included your Business on Local Business Directories:}

For a small business, being visible to consumers looking for a business or product in their area is extremely important. So it is very important to make your business site included in local business directories. In this way your customer can easily find out whenever they needed. For this check out where your competitors are listed and also make sure your business has been added to Google Maps, using the Local Business Center. Take the time to include all the relevant information you can publish about your business and update any old news. For many consumers, this will be their first interaction with the business so make sure that you appear in as many local searches as possible.

\section{Offers and Discounts:}

Building a strong community is the first part of social marketing. But using that community to increase sales, promoting marketing and increasing customer base is the true power of social media. One way to excitement among the community is to collectively do something to create an offer or discounts. You can also have a contest to create 
competition between users. A good social media contest should include some sort of sharing or commenting as a requirement for winning because with this contest automatically get viral. Discounts are also a great way to connect with your community. By giving coupons to your social community, you're rewarding and reminding them that you are not only a brand to engage with, but also to buy from.

\section{Conclusion:}

Social media applications in today's world become most efficient effective tool for small business entrepreneurs. Creating a basic social media presence is getting your business easily reach to target customers and by using in right approach social media helps to build a long term relationship with business and customer. social media applications has positive impact on small business entrepreneurs and entrepreneurs are highly motivated to use this platform because it requires minimum budget or even free in most social media websites to advertise their products and social media creates an interaction in which customer can also participate and social media provides real time feedback handling opportunities. There are various strategies to make social media as effective marketing tool. You should include your site in local business directories. By giving offers and coupons to your social community, you can reward and remind them. Taking advantage of these strategies can help you build your community, make your marketing more effective.

\section{References}

[1] GranovetterMS(1973)The strength of weak ties. American journal of sociology78: 1360-1380.

[2] Burt RS(2004)Structural Holes and Good Ideas. American Journal of Sociology110: 349-399.
[3] Shabbir MS (2015) Innovation and Competitiveness Lead to Industrial Trade. Business and Economics Journal6: 181.

[4] Cheung CMK, LeeMKO(2010)A theoretical model of intentional social action in online social networks. Decision Support Systems49: 24-30.

[5] MangoldWG, FauldsDJ(2009)Social media: The new hybrid element of the promotion mix. Business Horizons52: 357-365.

[6] Shahzad M, Rehman A (2015) Barriers to Service Quality in the Banks of Pakistan: A Comparative Study of Islamic and Conventional Banks. Business and Economics Journal 6: 178.

[7] BlackshawP, NazzaroM(2004)Consumer-Generated Media (CGM) 101: Word-of-mouth in the age of the Web fortified consumer.

[8] Bandura A(1986)Social foundations of thought and action: A social-cognitive theory.Englewood Cliffs, NJ: Prentice Hall.

[9] FulkJ, Schmitz J, SteinfieldCW (1990) A Social Influence Model of Technology Use. Sage, Newbury Park, CA.

[10] Daft RL, LengelRH(1986)Organizational information requirements, media richness and structural design. Management Science 32: 554-571.

[11] Evan D, Bratton S (2008) Social Media Marketing an Hour a Day: Wiley publishing.

[12] Social Media Marketing by www.wikipedia.com 